\title{
Su Stresine Toleranslı Yer Fıstığı (Arachis hypogaea) Hatlarının Belirlenmesi
}

\author{
Ali Beyhan UÇAK ${ }^{1} \quad$ A.Nuran Çí ${ }^{2} \quad$ M.Durak TÜYSÜZ ${ }^{3} \quad$ Hayri ŞAHİN $^{3}$ Ekin ŞARLI ${ }^{3}$ \\ ${ }^{1}$ Siirt Universitesi, Ziraat Fakültesi, Biyosistem Mühendisliği Bölümü - Siirt \\ ${ }^{2}$ Doğu Akdeniz Tarımsal Araştırma Enstitüsü Müdürlüğü Adana \\ ${ }^{3}$ Kahramanmaraş Sütçü İmam Üniversitesi Ziraat Fakültesi Biyosistem Mühendisliği Bölümü Kahramanmaraş \\ $\triangle$ : alibeyhanucak@gmail.com
}

Geliş (Received): 04.11.2017

Kabul (Accepted): 15.12.2017

\begin{abstract}
ÖZET: $\mathrm{Bu}$ araştırma, Çukurova koşullarında yetiştirilen 30 adet durulmuş (homozigot hale gelmiş) yer fistı̆̆ hattının su stresine toleransını belirlemek amacıyla 2015 ve 2016 yıllarında Çukurova Tarımsal Araștırma deneme arazisinde tesadüf blokları deneme deseninde üç tekerrürlü olarak yürütülmüştür. Sulama programı, etkili kök derinliğindeki mevcut nem \%50'ye düştüğünde tekrar tarla kapasitesine çıkaracak miktarda suyun damla sulama yöntemiyle uygulanması şeklinde oluşturulmuştur. Araştırma yıllarında dört sulama uygulaması yapılmıştır. Yapılan varyans analizi sonucunda genotipler arasındaki farkl1lıklar istatistiki olarak $(\mathrm{p}<0.01)$ önemli bulunmuştur. Çalışmanın iki yıllık LSD testi sonuçlarına (ortalamalarına) göre en yüksek verim (641.55 kgda-1), en düşük bitki su stres indeksine (CWSI=0.25) ve en yüksek klorofil içeriğine $(\mathrm{CC}=47.81$ spad) sahip 30 nolu hattan (Sultan) elde edilmiştir. En düşük verim ise (134.56 kgda-1) yüksek CWSI'ne ve düşük klorofil içeriğine sahip olan 20 nolu hattan (IP:85) elde edilmiştir. Araştırma sonucunda verim, CWSI ve CC açısından öne çıkan ve sulama suyunu optimum bir randımanla kullanan 30 nolu hat su stresine tolerant olarak tespit edilmiş ve su stresine dayanıkl1lı çalışmalarında değerlendirilebilir özelliklere sahip olduğu belirlenmiştir. SSL konusunda düşük verim elde edilen 20 nolu hat ise hassas olarak belirlenmiştir.
\end{abstract}

Anahtar Kelimeler: Bitki su stres indeksi, Klorofil içeriği, Su stresi, Yerfistığı

\section{Determination of Water Stress Tolerant Peanut (Arachis hypogaea) Lines}

\begin{abstract}
This study was carried out in three replications of randomized blocks trial design in Cukurova Agricultural Research trial land in 2015 and 2016 to determine water stress tolerance of thirty (30\%) homozygous ground loins grown in Cukurova conditions. The watering program was designed to apply the water to the soil at an effective root depth of 50\% to reduce the moisture content to $50 \%$ by drip irrigation. During the research years, four irrigation applications were made. As a result of the analysis of variance, differences between genotypes were statistically significant $(\mathrm{p}<0.01)$. The study yielded 30 lines (Sultan) with the highest yield $(641.55 \mathrm{kgda}-1)$, lowest plant water stress index $(\mathrm{CWSI}=0.25)$ and highest chlorophyll content $(\mathrm{CC}=47.81 \mathrm{spad})$ according to the two year LSD test results it was. The lowest yield (134.56 kgda-1) yielded 20 CWSI horns (IP: 85) with high CWSI and low chlorophyll content. As a result of the study, yield, CWSI and CC, 30 lines which use irrigation water with optimum efficiency, were determined as tolerant to water stress and determined to have evaluable properties in water stress endurance studies. On the other hand, 20 lines with low efficiency have been determined sensitively.

Key words: Crop water stress index; Chlorophyll content, Water stress, Peanut
\end{abstract}

\section{GíRIS}

Yerfistığ1 tohumları; içerdiği yă̆, protein, karbonhidrat, vitaminler ve madensel maddeler ile insanlar ve hayvanlar için değerli bir besin kaynağıdır. Yerfistığı bir baklagil bitkisidir. Bu nedenle, diğer baklagillerde olduğu gibi, havanın serbest azotunu toprağa bağlar ve kendisinden sonra ekilecek bitkiye azot ve organik maddece zengin bir toprak birakır (Arıoğlu ve Culluoğlu, 1993). Dünyada değerli bir yağ kaynağı, Türkiye'de ise çerez Yerfistığı (Arachis hypogaea); baklagil bitkisidir, tek yıllık ve yazlık olarak yetiştirilir. Türkiye'de üretimin yaklaşık \%70'i Çukurova bölgesinde gerçekleştirilmektedir. Osmaniye, Türkiye'de Adana'dan sonra en fazla yerfistığı üretimin yapıldığı ve en fazla bu üretime dayalı ticaret ve sanayinin geliştiği bir ildir. En son verilere göre, Türkiye'de üretimin \%41'i Adana'da, \%38.8'i Osmaniye'de, \%6.3'ü Aydın'da, \%4.3'ü Antalya'da, \%3.4'ü Mersin'de,\%1.2'si Muğla'da ve geri kalanı da diğer illerde yapılmaktadır.
Günümüzde agronomist ve bitki islahçıları bitkilerin yaşayabilmelerinden daha çok verimine odaklanmıştır. Sonuçta verimlilik esas alınmış, yüksek verim veren çeşitler öne çıkmıştır. Ancak son yıllarda küresel ısınmanın etkisiyle abiyotik stres faktörlerinin tarımsal üretimi olumsuz yönde etkilemesi, araştırıcıları iklim değişikliğinin zararlı etkilerine karşı yeni önlemler almaya zorlamıştır. Abiyotik stres etmenlerinin başında ise su stresi ve düşük ve yüksek sıcaklık gelmektedir. Yetersiz su koşullarında, bitki dokularında su stresi oluşmakta, bu da fotosentezde önemli düşüşlere neden olmaktadır. Bitkiler su stresinde tranpirasyonla su kaybını önlemek için stomalarını hızla kapatarak, yaprağa giren $\mathrm{CO}_{2}{ }^{\prime} \mathrm{i}$ sinırlandırılmaktadır (Chaves, 1991). Moroni et al., (2012) su stresini ölçmede en hızlı ve en doğru yöntemin kanopi (yaprak-taç) sıcaklığı (CWSI) olduğunu, bunun da 1slah çalışmalarında seleksiyon kriteri olarak kullanılabileceğini vurgulamışlardır. Buğday ve nohut bitkilerinde, su stresine tolerant genotiplerin tespit edilmesine yönelik 
çalışmalar yapılmasına karşın, yerfıstığı bitkisinin kuraklık stresine karşı tepkisini belirlemeye yönelik yeterli bilgiye ulaşılamamıştır. Bu bağlamda bu çalışma; doğal tarla koşullarında 30 adet yerfıstığı hattının verim, bitki su stres indeksi ve klorofil içeriği değerlerinden faydalanarak su stresine karşı mukavemetlerini belirlemek amacıyla yapılmıştır.

\section{MATERYAL ve YÖNTEM}

$\mathrm{Bu}$ araştırma, 2015 ve 2016 yıllarında Doğu Akdeniz Tarımsal Araştırma Enstitüsü araştırma ve deneme alanında doğal tarla koşullarında, tesadüf blokları deneme deseninde 3 tekerrürlü olarak yürütülmüştür. Araştırmada, bitki materyali olarak 30 adet yerfıstığı hattı kullanılmıştır. Bölge kışları ılık ve yağışı, yazları sıcak ve kurak geçen tipik Akdeniz iklim kuşağı içerisinde yer almaktadır. Toprağın elektriksel iletkenliği düşük, kireç oranı bitki yetiştiriciliği açısından sorun oluşturmayan, tuzluluk sorunu bulunmayan, killi-tınlı bünyeli toprak yapısındadır. Çalışma alanında kullanılan sulama suyu kalite sınıfi; alınan örnekler sonucunda $\mathrm{C}_{2} \mathrm{~S}_{1}$ olarak belirlenmiştir. Sulama suyunun elektriksel iletkenliği $0.34 \mathrm{dS} / \mathrm{m}$ ve $\mathrm{pH}$ 7.20 olarak tespit edilmiştir. Denemede kullanılan sulama suyu yerfıstığ sorun oluşturmamaktadır. Sulama programı 0-90 cm'lik etkili kök derinliğinde mevcut nem \%50'ye düştüğünde damla sulama yöntemiyle tekrar tarla kapasitesi çıkaracak kadar su uygulanmıştır. Sulama uygulamaları sayaçlardan geçirilerek kontrollü bir şekilde yapılmıştır. Sulamalardan önce $0-90 \mathrm{~cm}$ toprak nemi içeriği gravimetrik yöntem ile takip edilmiş, belirlenen nem içeriği, eşitlik 1 kullanılarak derinlik cinsinden neme dönüştürülmüştür.

$$
\mathrm{d}=\left(\mathrm{PwPw}_{\mathrm{AW}}\right) * \mathrm{As} * \mathrm{D} / 100
$$

Eşitlikte d; toprak neminin derinlik cinsinden su içeriği $(\mathrm{mm})$, Pw; tarla kapasitesi $(\%), \mathrm{Pw}_{\mathrm{Aw}}$; her bir katman için belirlenen nem (\%), As; toprağın hacim ağırlığı $\left(\mathrm{g} / \mathrm{cm}^{3}\right)$ ve $\mathrm{D}$; katman derinliği (mm)'dir. Verilecek su hacmi, toplam su miktarı, parsel alanı ve örtü yüzdesi ile çarpılarak eşitlik 2'ten hesaplanmıştır.

\section{$\mathrm{V}=\mathrm{d}_{\mathrm{T}} \mathrm{xAxP}$}

Eşitlikte V; parsellere verilecek su hacmi $(\mathrm{L})$ ve $\mathrm{d}_{\mathrm{T}}$; etkili kök derinliği $(0-90 \mathrm{~cm})$ için toplam su $\left(\mathrm{d}_{\mathrm{T}}\right)$ miktarı $(\mathrm{mm})$ ve A; parsel alanı $\left(\mathrm{m}^{2}\right)$ ve P:örtü yüzdesidir (\%). Çalışmada seçilen damlatıcı debisi toprağın infiltrasyon hızından düşük olduğu için yüzey akış gerçekleşmemiştir. Sulu konuda her defasında mevcut nemi tarla kapasitesine getirecek kadar sulama suyu uygulandığı için derine sızmadığı varsayımı yapılmıştır. Aylık ve sezonluk evapotranpirasyon değerleri su bütçesi yöntemine göre (Eşitlik 3) hesaplanmıştır.

$$
\mathrm{ET}_{\mathrm{a}}=\mathrm{P}+\mathrm{I}-\mathrm{R}_{\mathrm{f}}-\mathrm{D}_{\mathrm{p}} \pm \Delta \mathrm{S}
$$

Eşitlikte; $\mathrm{ET}_{\mathrm{a}}$ : Evapotranspirasyon $(\mathrm{mm}), \mathrm{P}$ : yağış $(\mathrm{mm})$, I: sulama suyu miktarı $(\mathrm{mm})$; $\mathrm{R}_{\mathrm{f}}$ : yüzey akış $(\mathrm{mm}) ; \quad \mathrm{D}_{\mathrm{p}}$ : derine sızma $(\mathrm{mm}) ;$ ve $\pm \Delta \mathrm{S}(\mathrm{mm})$ : kök bölgesinde toprak nem değişimi olarak ifade edilmiştir. Hasat , ekilen dört sıranın orta iki sirasından hesaplanmıştır. Bitki su stresi indeksinin (CWSI) belirlenmesinde Idso ve ark. (1982)'nın önerdiği ampirik yöntem kullanılmıştır. Anılan yönteme göre CWSI aşağıdaki eşitlik 4'ten hesaplanmıştır.

$\mathrm{CWSI}=[(\mathrm{Tc}-\mathrm{Ta})-\mathrm{LL}] / \mathrm{UL}-\mathrm{LL}$

Eşitlikte: CWSI, bitki su stresi indeksi, Tc, taç sıcaklığ $\left({ }^{\circ} \mathrm{C}\right)$; Ta, hava sıcaklığ $1 \quad\left({ }^{\circ} \mathrm{C}\right)$; LL, bitkide su stresinin olmadığı alt sınır (bitkilerin potansiyel hızda transpirasyon yaptığı sınır değeri); UL, bitkilerin tamamen stres altında olduğu üst sınırı (bitkinin transpirasyon yapmadığı varsayılan sınır değeri) göstermektedir. Klorofil içeriği (CC), yapraktaki klorofil miktarını dolaylı olarak ölçen, taşınabilir klorofil metre cihazı (Minolta SPAD- 502, Osaka, Japan) ile yapılmıştır. Klorofil içeriğinin 1'e yaklaştıkça arttığı, $\quad 0$ 'a yaklaştıkça azaldığı yaklaşımında bulunulmuştur.

\section{İstatistik analiz ve değerlendirme}

Araştırmadan elde edilen verilerin tesadüf blokları deneme desenine göre varyans analizi yapılmış ve önemli bulunan uygulamalar LSD testine (gruplama) tabi tutulmuştur. Analiz ve hesaplamalar JUMP 5.0.1a. İstatistik bilgisayar paket programında yapılmıştır. Özellikler arasındaki ilişkiyi belirlemek için korelasyon analizi yapılmıştır. İlişkilerin yönleri (pozitif veya negatif) belirlenmiştir. Analiz ve hesaplamalar JUMP 5.0.1a. istatistik bilgisayar paket programında yapılmıştır.

\section{BULGULAR ve TARTIŞMA}

Çalışmanın 1.ve 2. yılında, konulu sulama uygulamalarına etkili kök derinliğinde $(0-90 \mathrm{~cm})$ toprak nemi \%50'ye düştüğünde 11.07.2015/2016 başlanmış ve fizyolojik olum dönemi başında 19.09.2015/2016 tarihinde son verilmiştir. Toplam araştırma yıllarında dört kez sulama suyu uygulanmıştır. Uygulanan sulama suyu miktarı (iki yılın ortalaması) $411 \mathrm{~mm}$ ve bitki su tüketimi $463 \mathrm{~mm}$ olarak gerçekleşmiştir. Yapılan varyans analizi sonuçlarına göre verim, bitki su stress indeksi (CWSI), klorofil içeriği bakımından hatlar arasındaki farklılıklar istatistiki olarak $0.01 \quad(\mathrm{p}<0.01)$ düzeyinde önemli bulunmuş ve LSD testine (gruplama) tabi tutulmuştur. Ekte Çizelge 1 ve 2 'de LSD testi sonucu hatların sirasıyla ortalama verim değerleri (2015-2016), Çizelge 3 ve 4'de CC değerleri, Çizelge 5 ve 6'da bitki su stress indeksi (CWSI) değerleri, Çizelge 7'de ise korelasyon analizi verilmiştir.

Çalışmanın birinci yılında; en yüksek verim $(669,60$ kgda- $^{1}$ ), en düşük CWSI'e (0.24) ve yüksek klorofil içeriğine (49.05 spad) sahip olan 30 nolu hatta (Sultan) belirlenirken, en düşük verim $\left(160.80 \mathrm{kgda}^{-1}\right)$ yüksek CWSI'e ve düşük klorofil içeriğine sahip olan 20 nolu hatta belirlenmiştir. 
Çizelge 1. Genotiplerin 2015 yllı verim değerleri

\begin{tabular}{|c|c|c|c|c|c|c|c|c|c|c|c|c|c|c|c|c|c|}
\hline No & IP & Hatlar & & & & & & & & Grub & & & & & & & Verimi $(\mathrm{kg} / \mathrm{da})$ \\
\hline 1 & 332 & 30 & $\mathrm{~A}$ & & & & & & & & & & & & & & 669.60 \\
\hline 2 & 96 & 18 & & B & & & & & & & & & & & & & 618.60 \\
\hline 3 & 362 & 1 & & B & $\mathrm{C}$ & & & & & & & & & & & & 605.00 \\
\hline 4 & 105 & 22 & & $\bar{B}$ & $\mathrm{C}$ & $\mathrm{D}$ & & & & & & & & & & & 573.20 \\
\hline 5 & 344 & 15 & & & $\mathrm{C}$ & $\mathrm{D}$ & $\mathrm{E}$ & & & & & & & & & & 557.00 \\
\hline 6 & 342 & 23 & & & $\mathrm{C}$ & $\mathrm{D}$ & $\mathrm{E}$ & F & & & & & & & & & 555.60 \\
\hline 7 & 302 & 10 & & & $\mathrm{C}$ & $\mathrm{D}$ & $\mathrm{E}$ & F & $\mathrm{G}$ & & & & & & & & 545.65 \\
\hline 8 & 144 & 2 & & & & $\mathrm{D}$ & $\mathrm{E}$ & $\mathrm{F}$ & $\mathrm{G}$ & & & & & & & & 540.00 \\
\hline 9 & 29 & 8 & & & & $\mathrm{D}$ & $\mathrm{E}$ & $\mathrm{F}$ & $\mathrm{G}$ & $\mathrm{H}$ & & & & & & & 529.80 \\
\hline 10 & 308 & 5 & & & & & E & $\mathrm{F}$ & $\mathrm{G}$ & $\mathrm{H}$ & I & & & & & & 496.66 \\
\hline 11 & 329 & 3 & & & & & $\bar{E}$ & $\mathrm{~F}$ & $\mathrm{G}$ & $\mathrm{H}$ & I & $\mathrm{J}$ & & & & & 496.00 \\
\hline 12 & 1 & 16 & & & & & & $\mathrm{~F}$ & $\mathrm{G}$ & $\mathrm{H}$ & I & $\mathrm{J}$ & & & & & 495.20 \\
\hline 13 & 44 & 28 & & & & & & & $\mathrm{G}$ & $\mathrm{H}$ & I & $\mathrm{J}$ & & & & & 491.60 \\
\hline 14 & 336 & 24 & & & & & & & & $\mathrm{H}$ & I & $\mathrm{J}$ & $\mathrm{K}$ & & & & 478.40 \\
\hline 15 & HALİSBEY & 4 & & & & & & & & $\mathrm{H}$ & I & $\mathrm{J}$ & $\mathrm{K}$ & & & & 475.20 \\
\hline 16 & 71 & 25 & & & & & & & & & $\mathrm{I}$ & $\mathrm{J}$ & $\mathrm{K}$ & & & & 456.00 \\
\hline 17 & 38 & 12 & & & & & & & & & I & $\mathrm{J}$ & $\mathrm{K}$ & & & & 452.00 \\
\hline 18 & 30 & 21 & & & & & & & & & & $\mathrm{~J}$ & $\overline{\mathrm{K}}$ & $\mathrm{L}$ & & & 435.20 \\
\hline 19 & 3 & 13 & & & & & & & & & & & $\overline{\mathrm{K}}$ & $\begin{array}{ll}\mathrm{L} & \mathrm{M} \\
\end{array}$ & & & 417.40 \\
\hline 20 & 85 & 19 & & & & & & & & & & & & $\begin{array}{ll}\mathrm{L} & \mathrm{M} \\
\end{array}$ & $\mathrm{N}$ & & 382.40 \\
\hline 21 & 5 & 6 & & & & & & & & & & & & $\mathrm{M}$ & $\mathrm{N}$ & & 374.13 \\
\hline 22 & 42 & 11 & & & & & & & & & & & & $\mathrm{M}$ & $\mathrm{N}$ & & 367.40 \\
\hline 23 & 100 & 9 & & & & & & & & & & & & $\mathrm{M}$ & $\mathrm{N}$ & & 357.60 \\
\hline 24 & 7 & 26 & & & & & & & & & & & & & $\mathrm{~N}$ & & 351.60 \\
\hline 25 & 24 & 7 & & & & & & & & & & & & & $\mathrm{~N}$ & & 342.60 \\
\hline 26 & 119 & 29 & & & & & & & & & & & & & $\mathrm{~N}$ & & 342.00 \\
\hline 27 & 160 & 17 & & & & & & & & & & & & & $\mathrm{~N}$ & & 337.40 \\
\hline 28 & 45 & 14 & & & & & & & & & & & & & $\mathrm{O}$ & & 253.40 \\
\hline 29 & 125 & 27 & & & & & & & & & & & & & $\mathrm{O}$ & $P$ & 209.40 \\
\hline 30 & SULTAN & 20 & & & & & & & & & & & & & & $P$ & 160.80 \\
\hline
\end{tabular}

LSD $(0.05)=61.04$

Çizelge 2. Genotiplerin 2016 yılı verim değerleri

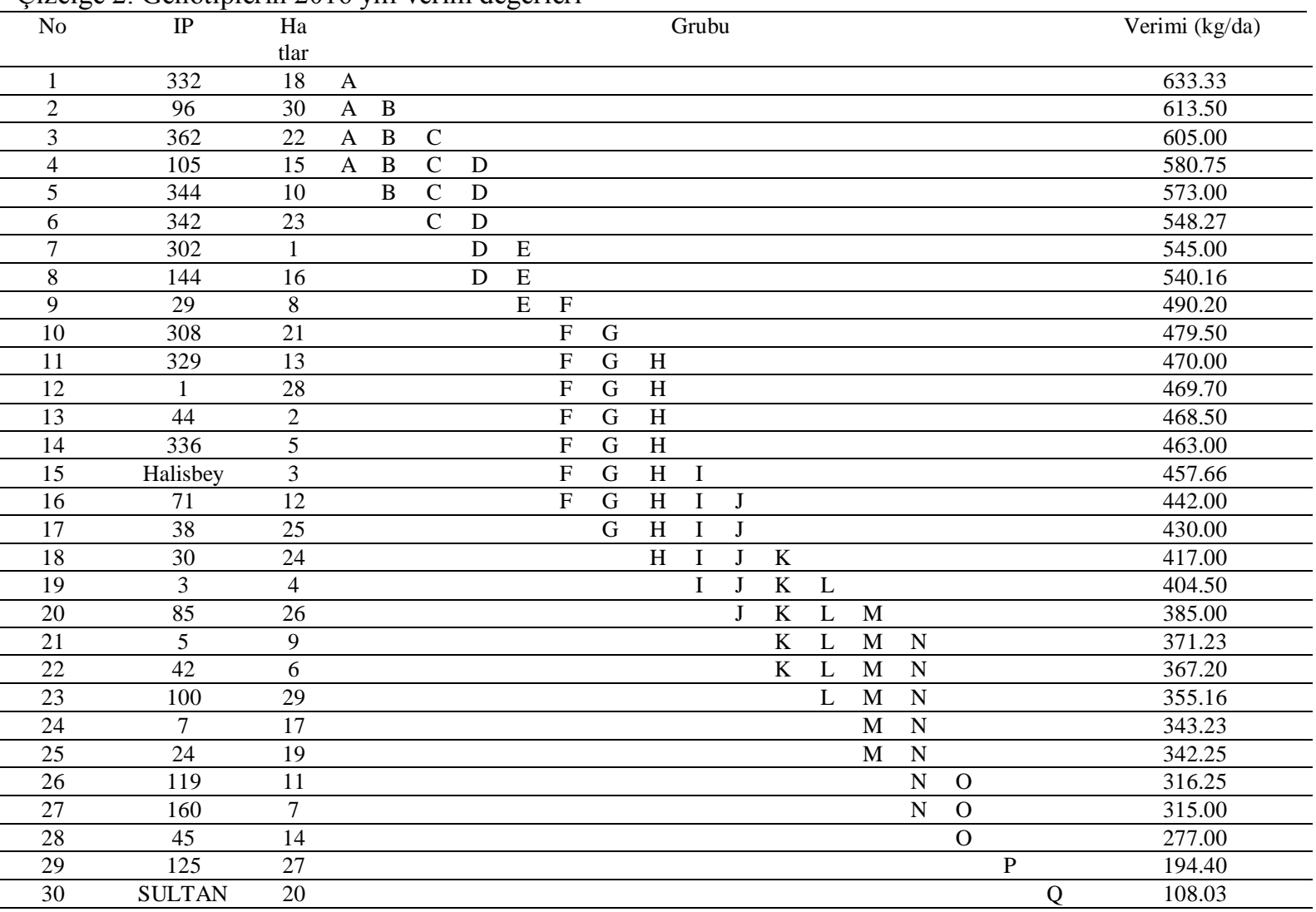

$\mathrm{LSD}(0.05)=57.23$; Htl: Hatlar 
Çizelge 3. Genotiplerin 2015 y1lı CC değerleri

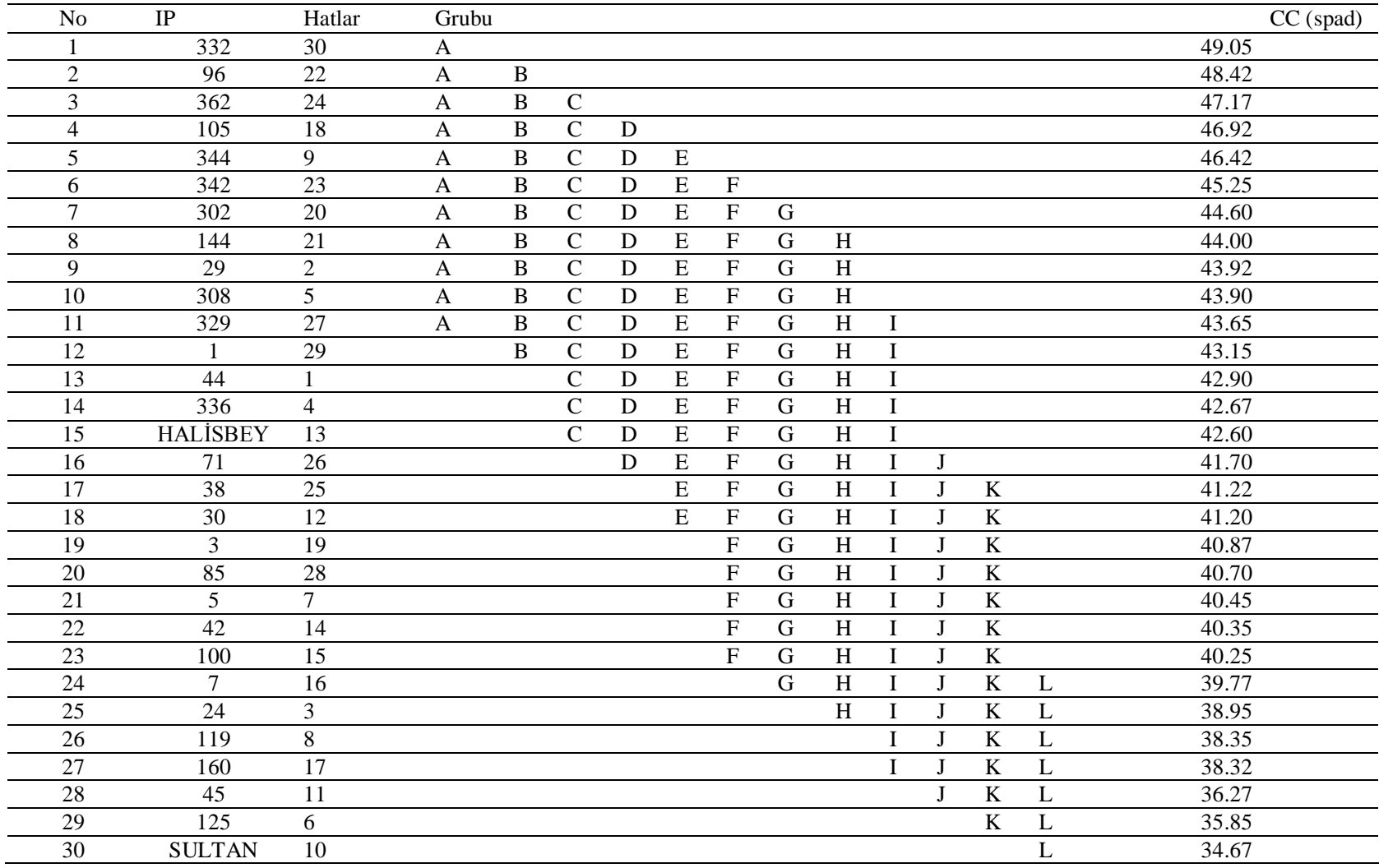

LSD $(0.05)=5.44 ;$ Htl: Hatlar

Çizelge 4. Genotiplerin 2016 yılı CC değerleri

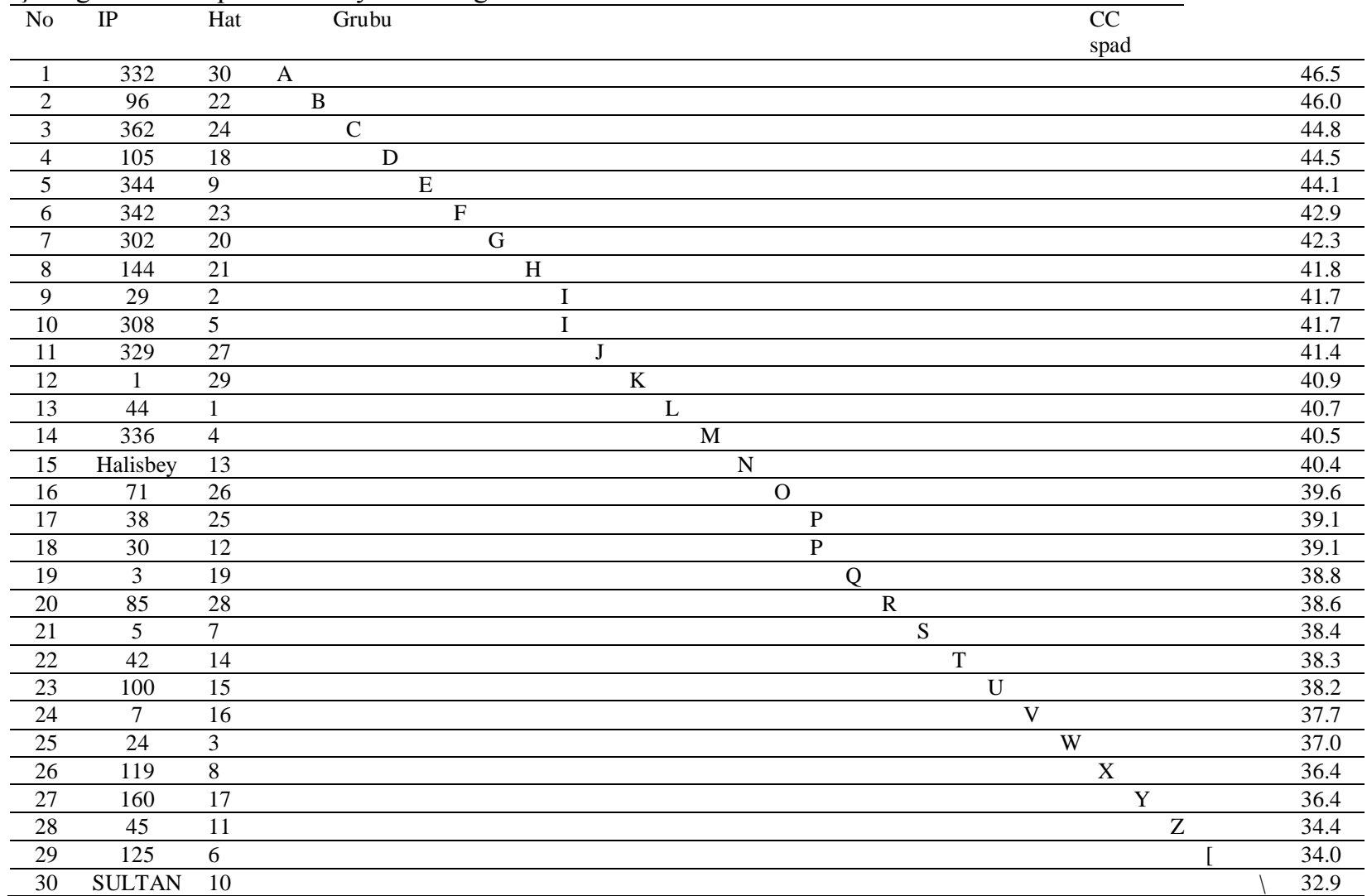

$\operatorname{LSD}(0.05)=0.026$ 
Çizelge 5. Genotiplerin 2015 yılı CWSI değerleri

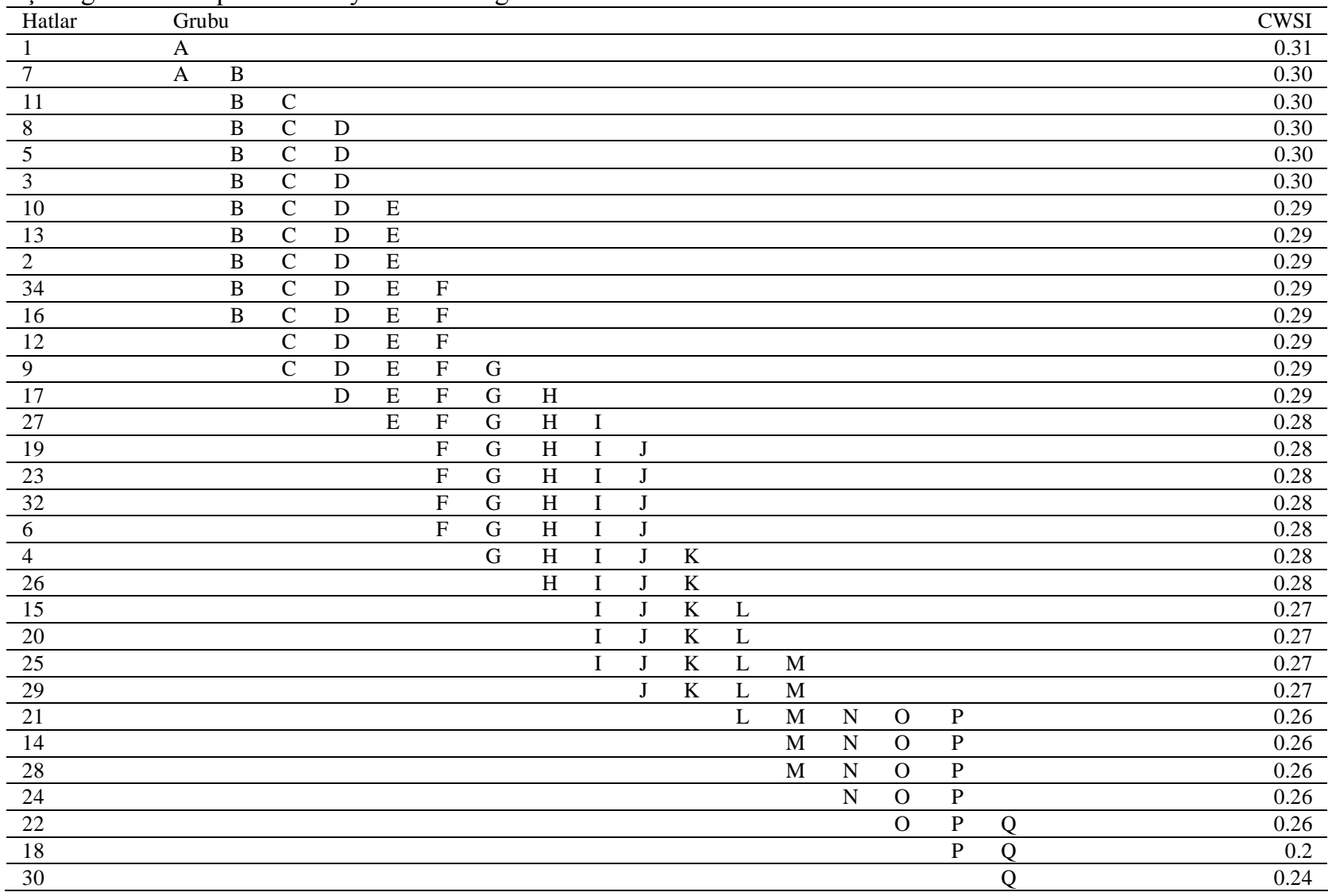

Çizelge 6. Genotiplerin 2016 yılı CWSI değerleri

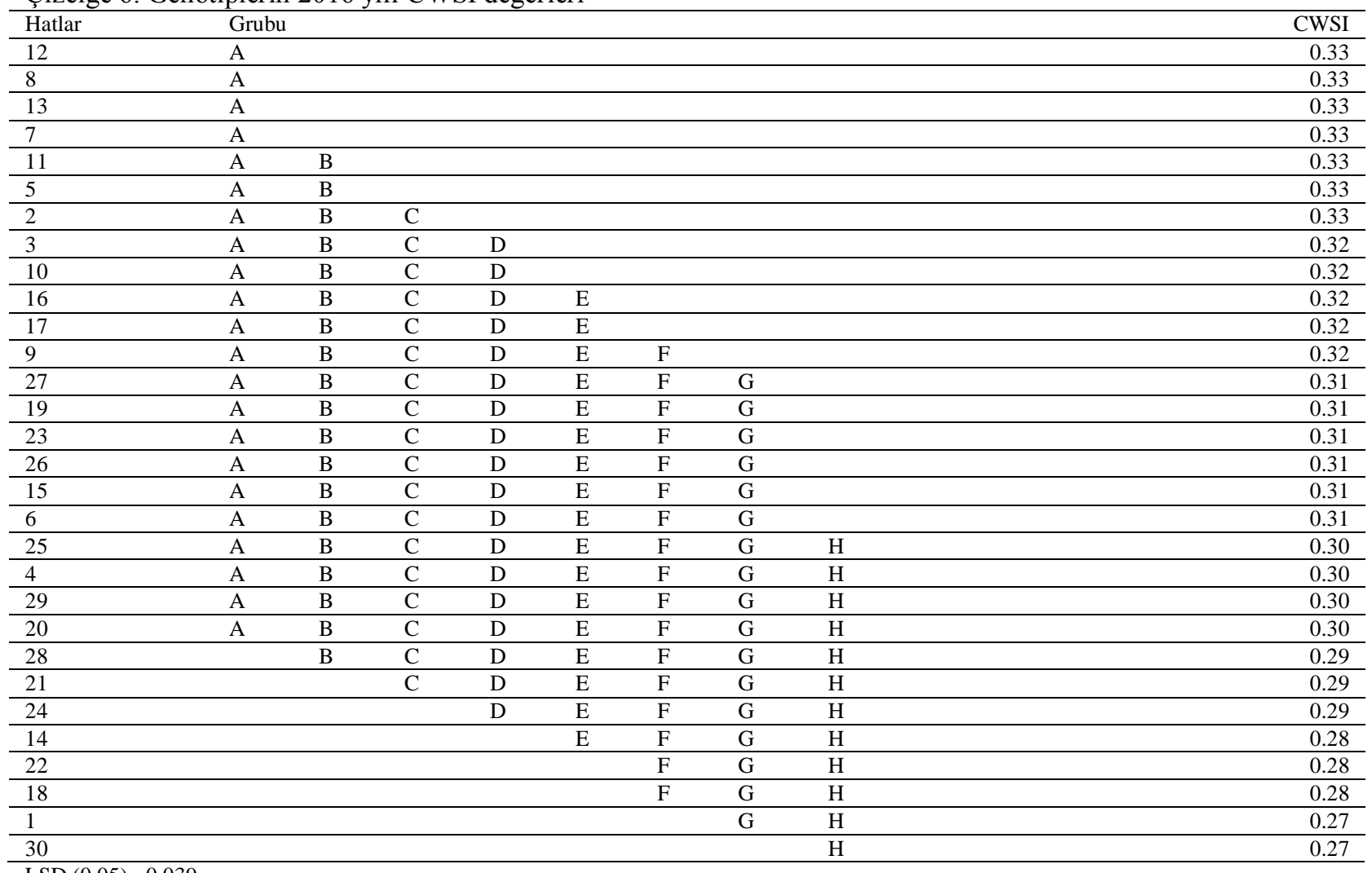

$\operatorname{LSD}(0.05)=0.039$ 
Çizelge 7. Verim ve kimi parametrelere ait korelasyon katsayıları

\begin{tabular}{|c|c|c|c|c|}
\hline & Verim & CWSI & $\mathrm{CC}$ & $\mathrm{ET}_{\mathrm{a}}$ \\
\hline Verim & 1.0000 & & & \\
\hline CWSI & $-0.7587 * *$ & 1.0000 & & \\
\hline$C C$ & $0.7711^{* *}$ & $0.3341^{\mathrm{ns}}$ & 1.0000 & \\
\hline$E T_{a}$ & $0.8444 * *$ & $0.8378^{* *}$ & $0.2832^{\mathrm{ns}}$ & 1.0000 \\
\hline
\end{tabular}

**: $\mathrm{p}<0.01$. ns:Not significant. CWSI: Bitki su stress indeksi. CC: Klorofil içeriği.

ETa: Mevsimlik bitki su tüketimi

Çalışmanın birinci yılında; en yüksek klorofil içeriği (49.05 spad) 30 nolu hatta (Sultan) belirlenirken, en düşük klorofil içeriği (34.67 spad) 10 nolu hatta belirlenmiş̧ir. Çalışmanın birinci yılında; en yüksek CWSI'i $1(0.31)$ ve 7 (0.30) nolu hatta belirlenirken, en düşük CWSI'i (0.24) 30 nolu hatta belirlenmiştir.

Çalışmanın ikinci yılında; en yüksek verim 18 (633.33 $\left.\mathrm{kgda}^{-1}\right), 30\left(613.50 \mathrm{kgda}^{-1}\right), 22$ (605.00 kgda$\left.{ }^{1}\right), 15$ (580.75 $\left.\mathrm{kgda}^{-1}\right)$ hatlardan elde edilmiştir., en düşük verim $\left(108.03 \mathrm{kgda}^{-1}\right)$ yüksek CWSI'e ve düşük klorofil içeriğine sahip olan 20 nolu hatta belirlenmiştir.

Çalışmanın ikinci ylında; en yüksek klorofil içeriği (46.58 spad) 30 nolu hatta (Sultan) belirlenirken, en düşük klorofil içeriği (32.94 spad) 10 nolu hatta belirlenmiştir.

Çalışmanın ikinci yılında; en yüksek CWSI'i 12 $(0.338)$ ve $8(0.335)$ nolu hatlarda belirlenirken, en düşük CWSI'i (0.27) 30 nolu hatta belirlenmiştir.

Korelasyon analizi; Yer fistığı hatlarının verim, klorofil içeriği (CC), bitki su stres indeksi (CWSI) ve bitki su tüketimi (ETa) arasındaki ilişkilere ait korelasyon katsayıları (r) Çizelge 7'de verilmiştir.

Sonuç olarak, korelasyon katsayılarına (r) bakıldığında tüm incelenen özellikler arasında istatistik olarak önemli ilişkiler $(\mathrm{p}<0.01)$ olduğu belirlenmiştir. Klorofil içeriği $(\mathrm{CC})$ ve verim arasında $\mathrm{r}=0.7711$ gibi yüksek bir artan ilişki bulunurken, CWSI ve verim arasında $r=-0.7587$ gibi yüksek bir azalan ilişsi bulunmuştur. Bitki su tüketimi (ETa) ve verim arasında ise $r=0.8444$ gibi yüksek bir artan ilişki belirlenmiştir

\section{SONUC}

Sulama, Çukurova koşullarında bitkilerde boyca ve fizyolojik düzeyde pek çok değişikliklere neden olmaktadır. Aşırı su kısıntısı (sıfır su), bitkinin büyüme ve gelişimini olumsuz yönde etkilemekte ve bitkiden sıfır verim alınmasına sebep olmaktadır. Sonuç olarak su kullanım etkinliğini artırmaya yönelik çalışmalarda veya su stresine dayanıklı hatların belirlenmesinde CWSI ve CC değerlerinin stres tarama parametresi olarak kullanılabileceği söylenebilir. Öte yandan araştırma yıllarında benzer performans gösteren, düşük CWSI, yüksek CC'e ve verime sahip olan 30-18- ve 22 nolu hatların diğerlerine kıyasla su stresine daha mukavim olduğu belirlenmiştir. Su kullanım etkinliğini arttırmaya yönelik çalışmalarda veya su stresine dayanıklılık çalışmalarında değerlendirilebilir özelliklere sahip olduğu belirlenmiştir. Öte yandan 20 nolu hattın ise hassas olduğu tespit edilmiştir.

\section{TEŞEKKÜR}

Doğu Akdeniz Tarımsal Araştırma Enstitüsüne verdikleri maddi ve teknik destekten dolayı teşekkur ederiz.

\section{KAYNAKLAR}

Arığlu H.H, Çulluoğlu N 1993. Çukurova Bölgesine Uygun Yerfistığı Çeşitlerini Belirlemek

Amacıyla Aynı Yerde Yürütülen üç Yerfistığı Verim Denemelerinin Birlikte Analiz Yöntemine Göre Değerlendirilmesi. Ç.Ü. Ziraat Fakültesi Dergisi, 8 (4) : $1-14$.

Chaves M.M 1991. Effect of water deficits on carbon assimilation. Journal Exp. Bot., $\quad 42,1-16$

Moroni I. F, M. Fraysse, A. Presotto, M. Cantamutto. 2012. Evaluation of Argentine wild sunflower biotypes for drought stress during reproductive stage. Proc. $18^{\text {th }}$ international Sunflower Conference, Mar del Plata, Argentina. 420-425

Idso S.B 1982. Non-Water-Stressed Baselines: A Key to Measuring and Interpreting Plant Water Stress. Agric. Meteorol., 27: 59-70. 